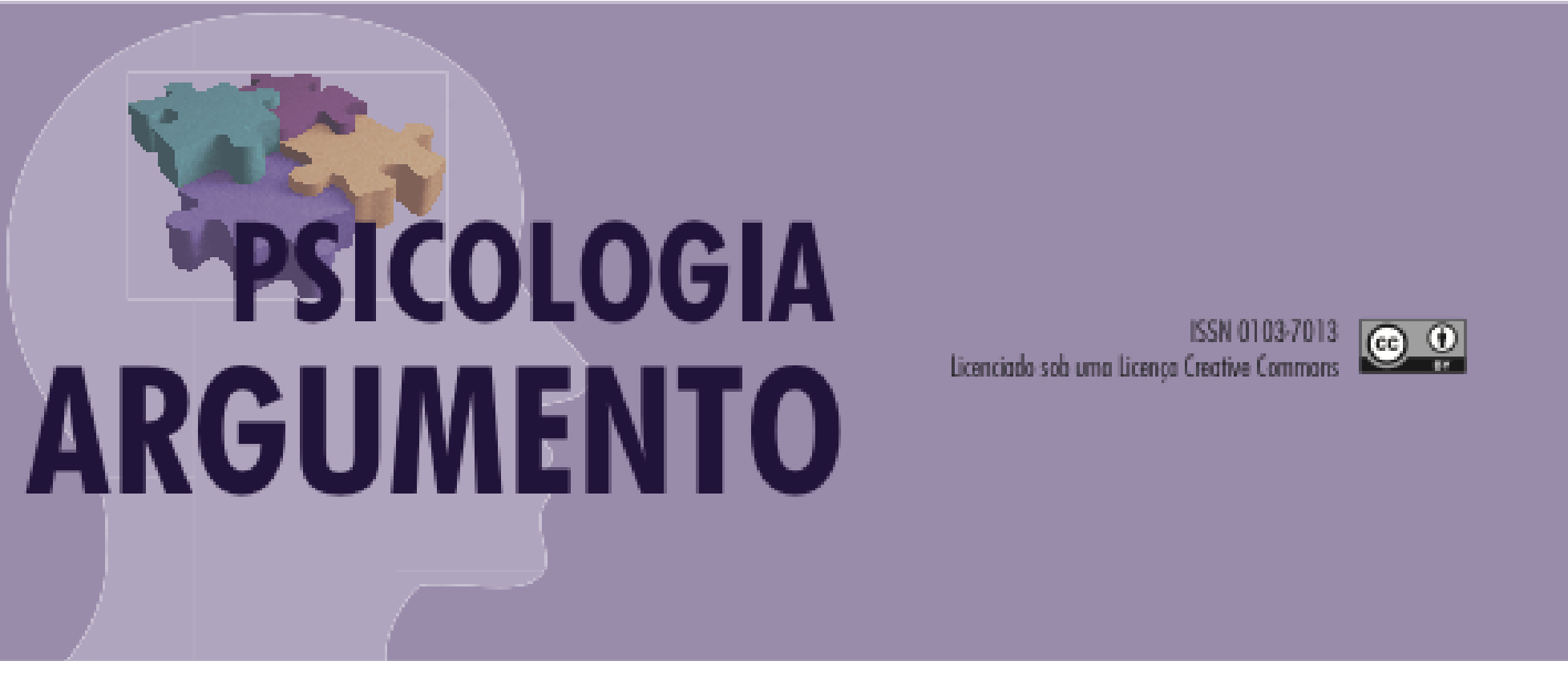

doi: http://dx.doi.org/10.7213/psicolargum.36.93.AO02

\title{
Abuse suffered by parricides in childhood.
}

Abuso sofrido por parricidas na infância.

Abuso sufrido por parricidas en la infancia.

Ana Maria Freitas Teche ${ }^{[a]}$

${ }^{[a]}$ E-mail: psi_anateche@hotmail.com

Paula Inez Cunha Gomide ${ }^{\text {[a] }}$

[a] Universidade Tuiuti do Paraná, docente do Mestrado em Psicologia Forense Praça da Ucrânia, 80, apartamento 162. CEP 80 730-430, Curitiba Paraná.

paulainezgomide@gmail.com

\section{Resumo}

O propósito desse estudo foi identificar práticas parentais de educação e condições de maus tratos físicos, psicólogicos e sexuais tolerados por parricídas que estão presos na polícia civil do Estado do Paraná. Participaram do estudo dois patricidas e um matricida, todos homens, com idades de 27,39 e 42 anos. Foram usados dois instrumentos para coleta de dados: uma entrevista estruturada e o Inventário de estilos parentais (Gomide, 2006). Os dados foram apresentados como estudos de caso. Posteriormente foi realizada uma história de maus tratos. Os índices de estílos parentais marcaram alta pontuação e todos os parricidas tiveram uma infância marcada por maus tratos físicos e emocionais e negligência, sendo que dois deles reportaram abuso sexual na infância. Esse estudo enfatiza a necessidade de estudar opções de intervenção e tratamento direcionada para ressocialização de parricidas.

Palavras-chave: Parricídio, maus tratos, infância 


\begin{abstract}
The purpose of this study was to identify parenting education practices and physical, psychological and sexual maltreatment endured by parricides committed to prisons and Civil Police Stations of the state of Paraná. Two patricides and one matricide individuals participated in the research, all male, aged 27, 39 and 42 years old. Two instruments were used to gather data: a structured interview and PSI - Parenting Style Inventory (Gomide, 2006). The data wered presented as Case Studies. Later similarity analysis on maltreatment history were performed. Parenting style indexes received risk scores. All parricides had a childhood marked by physical and emotional maltreatment and negligence, being that two of them reported sexual abuse in childhood. This study emphasizes the need of studying intervention options and treatments aimed at the social reintegration of the parricide.
\end{abstract}

Keywords: Parricide, maltreatment, childhood.

\title{
Resumen
}

Esta investigación tuvo como objetivo identificar prácticas educativas parentales y malos tratos (físicos, psicológicos e sexuais) sufridos por parricidas, presos en cárceles del Estado de ParanáBrasil. Dos parricidas y una matricida, todos del sexo masculino, de 27, 39 y 42 años de edad. Fueron usados dos instrumentos para colectar los datos: una entrevista estructurada y el Inventario de Estilo Parental. El historial de malos tratos fueron desarrollados posteriormente y los datos fueron descritos como estudio de caso. Los índices de los estilos parentales mostraron puntuaciones de riesgo y todos los parricidas tuvieron una infancia con abuso físico, emocional y negligencia. Dos participantes informaron que fueron abusados sexualmente en la infancia. La investigación hace hincapié en la necesidad de estudiar formas de intervenciones y tratamientos buscando la reintegración social de los parricidas.

Palabras clave: parricidio, malos tratos, infancia.

\section{Introdução}

Parricide, although a rare crime, that occurs in only $2 \%$ of the homicides (Heide, 2013; Gomide, 2010; Palermo, 2010), triggers strong emotional reactions among the public, media and law professionals. Understanding family relationships among these individuals and their victims can elucidate the motivations of the crime.

Men constitute the majority of abusers and victims in parricide (Heide, 1993, 2011; Hillbrand, Alexandre, Young \& Spitz, 1999; Pagani \& cols 2004; Heide, 2003; Heide \& Petee, 2007; Marleau, Millaud \& Auclair, 2003; Walsh, Krienert \& Crowder, 2008; Roe-Sepowitz, 2009; Ferreira, 2010; Shon \& Roberts, 2010; West \& Feldsher, 2010; Myers \& Vo, 2012). In 246 parricide cases in Brazil analyzed by Gomide and cols (2013), 71\% of the crimes were practiced against fathers, $25 \%$ against mothers and $4 \%$ against both; $86 \%$ of the crimes were committed by men and $14 \%$ by women. These 
statistics are similar to those found by Marleau (2002), Boots and Heide (2003) and Shon and Roberts (2010).

Most crime motivations described in the literature refer to child abuse (Heidi, 2013; Gomide, 2010; Ferreira, 2010). Parricides commit the crime in self-defense or in attempt to defend other family members, such as mother and siblings (Heide, 2003; Heide \& Petee, 2007; Hillbrand, 2010; West \& Feldsher, 2010). Abuse suffered during childhood has cumulative effects, therefore intensity, frequency and duration of the abuse can become the trigger factors to the crime (Myers e Vo, 2012; Weisman \& Sharma, 1997).

Child maltreatment may be of physical, sexual or of neglect order (Heidi, 2013) and all them are related to antisocial behavior or offensive attitude. Patterson, Reid and Dishion (1992) when describing The Vile Weed: Stages in the Coercion Model (pp 13) emphasized parents and grandparents poor educacional and antisocial practices as determinants for the development of antisocial behavior in children. Gomide $(2003,2006)$ related child physical abuse (spanking, beating) to the development of antisocial behavior in adolescence. Rocha (2012) through analytical-behavioral psychotherapy of high risk adolescent offenders identified child maltreatment (high neglect, beatings, sexual and psychological abuse) in the life stories of her clients.

Parricide experts often report various types of abuse suffered by homicides. The Richthofen case, of great impact on Brazilian media, in which a daughter with the help of her boyfriend killed both parents, illustrates several types of abuse suffered by the young girl. Casoy (2006) states that the parricide's testimony defined the family disagreements as chronic, with constant physical and psychological abuse. The parents spanked their daughter in front of her boyfriend. On several occasions the father threatened to beat his future son-in-law saying "One of these days, I will beat this kid up!" (p. 65). Heide (2011) reported the case of a 16-year-old boy who killed his father with a shotgun to stop years of verbal and physical abuse perpetrated by the father against the whole family and sexual abuse perpretated against his sister.

Parricide processes analyzed by Ferreira (2010) found family disharmony and parent-child relationships marked by quarrels and disagreements in almost all cases, supported by Sadoff (1971) data. Gomide (2010) reported the case of a 16-year-old boy who stabbed his mother after suffering physical (beatings, burns), psychological (constant humiliation), sexual (sleeping on his mother's bed, caressing, mouth kissing, sexual 
organs manipulation) maltreatment and neglect (not receiving affection, proper food and medical care).

Additionally to psychological symptoms resulting from child maltreatment, biological symptoms such as Post-Traumatic Stress Disorder (PTSD) (American Psychiatric Association, 2000) related to depression, dissociation, auto and hetero aggressive behaviors, chronic feelings of guilt and shame (Pagani e cols, 2004) were found. Child maltreatment, especially neglect, is associated with insecure attachment (Bolwby, 1988). The limbic system in these individuals remains alert, favoring poor judgment, preventing trust and triggering violent aggressive reactions. Myers e Vo (2012) found that youngsters maltreated by their parents lived under a sense of danger and constant fear in their homes, feared the next episode of abuse and were always alert. Such excessive surveillance can be a risk factor for violent behavior.

For Eckstein (2004), child abuse usually begins with episodes of verbal abuse which over time increase in frequency and intensity, turning into emotional and physical abuse when the desired response is not obtained. According to Walsh and Krienert (2009), this process progressively becomes harder for some children to bear, especially for the male, to the point that they commit patricide.

Children submitted to strong violence present anxiety, depression, mood swings, post-traumatic reactions, suicidal thoughts and dysfunctional behaviors, such as escape, abuse of alcohol and drugs and aggressive behavior towards parents, often coming to parricide (Heide, 1993; Brezina, 1999; Hillbrand, \& et al, 1999). Instead of providing stability and security, these parents become threatening figures (Eisikovits, Winstok, \& Enosh, 1998). In one case described by Ferreira (2010), the daughter killed her father with an iron bar when he attacked her mother with a knife. The father was an alcoholic and drug user, held police records for theft and was violent with all the family. According to Heide (2013), these youngsters feel physically and psychologically threatened or perceive that the life of other people are in danger. They kill due to terror and despair. One of the parricides studied by Pinheiro (2011) reported killing his father to free himself from the pressure exerted on him. "After killing him it seemed I was free. I felt free from the anguish" (p. 72).

The crime is often committed violently, with rampant beatings or stabbings, defined by Weisman and Sharma (1997) as exaggerated violence. This action impairs the framework of crime as self-defense. Brazilian law (Art 25) defines self-defense as 
"moderately using the necessary means to repel unjust aggression, actual or imminent, to the self or someone else." Although literature (Singnhal \& Dutta, 1990; Heide, 1992; Gomide, 2010; feldsher \& West, 2010; Heide, 2013) suggests that most individuals who kill their parents have experienced child maltratment perpetrated by their victims, law considers parricide a heinous crime, with aggravating circumstance of killing ascending or descending (Art. 121, combined with art. 61, paragraph "and" all the Brazilian Penal Code, 2007).

The aim of this study was to identify parental practices and maltreatment (physical, psychological and sexual) occurred in the relationship of parricides and their victims.

\section{Method}

Participants: This study included two patricides and one matricide, all male, aged 27, 39 and 42 years respectively, who were serving time in Prison Units or in a Civil Police Station of the state of Paraná.

Instruments: Two instruments were used for data gathering: a) A structured interview to collect data about educational level, working history, parent-child relationship, maltratmente (physical, psychological, sexual abuse and neglect) and the description of the crime day b) Parenting Styles Inventory [Inventário de Estilos Parentais] (Gomide, 2006), a Brazilian instrument to evaluate parental strategies used to educate children. The instrument has 42 questions about seven parental educational strategies, two positive ones: (A) positive monitory and (B) moral behavior, and five negatives ones: (C) inconsistent punishment, (D) negligence, (E) relaxed discipline, (F) negative monitoring and $(\mathrm{G})$ physical abuse. In order to obtain the Parental Style Score, positive strategies are added $(\mathrm{A}+\mathrm{B})$ and the sum of negative strategies is subtracted $(\mathrm{C}+\mathrm{D}+\mathrm{E}+\mathrm{F}+\mathrm{G})$. Parental Style Score varies from +24 (excellent) to - 60 (highly risk). All the questions are answered in a 3-point Likert scale: Always (2), Sometimes (1) and Never (0). The values of each parental practice range from 0 to 12 , so the closer to 12 , the greater the presence of a certain form of education on the relationship between parents and children.

Procedure: Data gathering started after the approval of the Ethics Committee (230 647, approved on 26.03.2013) and the authorization of the Director of the Penitentiary Department of the State of Paraná. Parricides were identified in a previous research 
conducted by Gomide et al (2013), that raised 246 names of Brazilian parricides collected nationwide, 43 of them from Paraná. The Director of the Penitentiary Department of the State of Paraná provided the names and the location of these individuals in the prision units. Only three parricides from the list were serving sentence in prisons, and all of them agreed to participate by signing the written consent form. Interviews were recorded and later transcribed for analysis. Interviews lasted 6 hours on average, in two episodes.

\section{Results}

Data of the three cases studied will be presented, highlighting positive and negative parental practices used by the caretakers of the parricides and the existence or not of abuse during childhood.

\section{CASE 1}

Patricide, 24 at the time of the crime (27 years old now), single and waiting for his sentence when the research was conducted. He lived with his parents and two brothers, and attended school up to high-school sophomore year. Since the age of seven he worked in construction as a bricklayer assistant after his father imposition. As adolescent he worked freelance with fittings and construction. He had a good relationship with his work colleague, although his romantic relationships were casual.

Maltreatment suffered during childhood was gradually revealed. Ever since he was a child his father spanked him (by punching, kicking, shoving, slapping and using objects such as belts, slippers, light wires, laths, iron and broom handles). One of the beatings was so hard that he and one of his brothers needed their mother's assistance to be fed, as the bruises on their hands did not permit them to use a spoon. Scars and bruises were common, and family members and neighbors witnessed the beatings but when they tried to intervene were ignored by the father. The patricide began defending himself against his father's aggressions during adolescence by running away or responding to aggression. In response to the reactions of his son the father would make use of iron bars, laths and even knives. He moved away from home in order to avoid further conflicts, but returned. Violence increased over time, to the point that the children were being constantly 
humiliated in public and slapped in front of friends without apparent reason. Threats and verbal abuse were frequent.

At the age of 14, the interviewee hit rock bottom after starting using drugs with friends, mainly crack and alcohol. He was involved with the police for robbing in order to buy drugs. His mother mentioned that his father was an alcoholic, drug user, and was sentenced by law due to diverting a cement cargo. A quarrel with their neighbor led to the father being shot and become handicapped. He had a 38 revolver. The mother was constantly mediating conflicts between father and children by stepping between quarrels and advising the children to avoid fights with their father.

On the crime day, the interviewee arrived home drunk and his father did not allow him to get inside the house. The son replied by stating: "I am your son and that's my house". The two started a physical dispute and had to be separated by his mother. The son then went to a bar nearby and kept drinking. In his way back he met his father walking towards him with the intent of hurting him. In self-defense, the patricide picked up a large rock and hit his father's head, causing a fatal injury. The police arrived shortly and arrested him red-handed.

Data from the Parenting Styles Inventory (Gomide, 2006) showed that the mother monitored her son's activities poorly (9), although she had great moral values (10). She had high scores of negligence, stressful monitoring, a demanding attitude and absence of clear educational rules (8). The mother's positive points were the absence of physical abuse and the minor impact of mood changes in his education.

On the other hand, his father had a score of parenting practices classified as risky (-15) for not monitoring his son's activities or showing affection (positive monitoring = 3), severely punishing his son (physical abuse $=9$ ) and being extremely negligent (10). Despite all these negatives aspects, his son gave him high scores for moral behavior (11), for always discerning right from wrong. In summary, the victim was a violent physical abuser and a negligent parent. He did not monitor any of his son's activities and did not show affection or empathy towards him. The youngster was always punished regardless of his father's mood. The patricide wrongly evaluated his father's excessive control about right and wrong as a moral value, as when he was severely spanked after picking a fruit from a neighbor's tree. His mother who could have been be a protective figure also showed a parental style of risk, i.e., poor positive monitoring, high negligence and stressful supervising, who constantly oscillated about rules to be followed. 


\section{CASE 2}

Patricide, 42 (39 at the time of the crime), divorced, father of three. He was sentenced to 16 years of seclusion. During childhood, he lived with his parents, two sisters, three brothers and his grandfather on his father's side. His father did not have a job, although he demanded money from his kids and his wife. The mother died three days after being assaulted by her husband when the participant was 13. After this event, the father decided to send his children to different family members. The patricide ended up living with an uncle (his mother's brother), his wife and their son for three years. He described this period as a wonderful experience. At 16, he moved to another town, to live with one of his brothers and get a job.

Work was always a priority in detriment of school, which he did not attend for long; instead, worked on the fields with his mother, collecting cotton, and later worked in construction as a hodman. He maintained a good relationship with his bosses and colleagues and had no trouble performing his duties. At 22, he met his wife with whom he lived for 17 years. She had been his only girlfriend. They had three children. Their relationship was described as calm, with few conflicts. At the age of 23 , he started smoking marijuana with his coworkers and at the age of 38 he started using crack with his brother-in-law (his wife's brother) for six months. He was hospitalized for 21 days for treatment. During this period his wife asked for divorce. He never got over the separation and felt unable to develop a relationship to another woman. He wished to be with her and their kids until the end of his life. Only his sons visited him in prison. His eldest daughter, age 17, writes letters because she doesn't feel confortable to visit him in prison.

He was beaten by his father (the victim) since childhood. His father would attack him by punching, kicking, shoving, slapping, pulling hair, clubbing, stoning, throwing bricks, knives, and other objects that were within reach. Bruises and cuts were common. His father was an alcoholic, always distant and extremely violent to the whole family. He grew up watching his father beat his mother, his brothers and his grandfather, who was also an alcoholic. The children were forced to work and the father demanded all the money they earned in order to buy alcohol and go to a whorehouse. "I never saw my father work in his life; he did get us to work, but he stayed in the shack, and by night he woul leave the house to visit whorehouses, come back home drunk and beat my mother.

PsicolArgum. 2018 jul./set., 36(93), 296-312 
We never called him father; to tell you the truth, I do not know what it is like to have a father."

He frequently witnessed his father grab his mother by the hair and rub her face on the wall. He does not like to recall this scenario because she would always leave with blood on her face. His mother was present, protected the children from their father, but died precociously victim of his father's abuse. The children were forbidden to seek medical care in order to hide the abuse. The parricide presented scars resulted from his father's attacks (a big one on the back of his right leg, one in his arm and one on his forehead). Family and neighbors witnessed several episodes of agression, but did not take action. His father was also aggressive towards neighbors. After he got married, neighbors would frequently call him to stop fights between his father and his brothers and also to prevent injuries to his stepmother. The abuse worsened over time. After divorce, the patricide faced financial problems not being able to afford house rental and was forced to move in with his father. His father repeated at this time what he used to do wih his mother: made him clean the house, wash clothes, cook and serve him food. His father would often throw food on his children's faces as they ate, and would sometimes deny them food. They could not perceive any signs that aggression was coming.

His father was a violent physical abuser, highly negligent, alcoholic, who would punish them more violently when drunk. His Parental Style Score was -27 (extremely negative and of high risk), he showed no sign of moral behavior (0) or positive monitoring (0) during the parricide's childhood and adolescence. His mother was present and tried to protect his children from the abusive father. She had a parental style score of +16 , i.e., a very good one. She showed proper moral behavior, monitored her children's activities with affection and was not abusive. However she died young and left the children with their abusive father.

On the crime day, he got home from work, made dinner and went to sleep as usual. He was already sleeping when his father arrived and violently pushed his bedroom door, asking him to make dinner. He replied that dinner had already been cooked. His father took his blanket away and asked him to heat dinner and serve him. He demanded for some juice and after complaining that the juice was hot, threw the glass against the wall and called his son a "cuckold". At this moment the parricide took an iron bar and hit his father on the back of his neck, who said: "you can kill me, son, I deserve to die, I am paying for everything I did." The parricide hit his father's head twice, lit up a marijuana cigar and 
waited for his father to "to finish dying ". He slept over his sister's house. The next day he returned home and called the police to tell his father had been killed. As the police investigators registered the occurrence, they noticed blood on his pants. He surrendered and revealed details of the crime.

\section{CASE 3}

Matricide, age 39 (35 at the time of the crime), single. He was sentenced to 14 years and six months of reclusion. His mother was a single mother. She had been abandoned by the father after being informed about the pregnancy. He was raised by his grandmother up to the age of eight and received sporadic visits from his mother. His grandmother was very strict and used to hit him for minor issues. At 10, in order to study, he moved to an uncle's house, who was also very strict but more caring than his grandmother. At the age of 11 , he moved in with his mother, who he would barely see. She left early for work and came back late, when he was already asleep. He missed affection, care and attention.

He studied up to the 5th grade and at the age of 12 he left school in order to work. Since early age, he helped his grandmother in her small farm, cutting wood, mowing lawn and helping with other farm work. He also worked with serigraphy where he was employed for a significant time. He enjoyed this type of work and adopted it as a profession. Later he set up his own screen printing business.

He was severely abused during childhood. His grandmother spanked him with broom handles, quince branches, rattan sticks, whips or other objects that were within her reach to punish him for just about anything. He never knew the reasons for these aggressions. Bruises all over his body were common. Family members witnessed the abuse, but deemed them common for they had been raised the same way. His uncle once reprimanded his grandmother for using a whip, but she did not listen. When living with his mother he felt less watched, lived practically alone, although she was also very strict "the same way as my grandmother". She would slap him, hit him using belts, slippers and sometimes broom sticks. During adolescence, he started to defend himself from her abusive behavior. Whenever his mother abused or ignored him, he felt hurt, sad, ashamed and punished himself.

Psychological abuse was also constant in his life. His mother frequently humiliated him by saying he would never achieve anything in his life. She would refrain from showing him affection and attention. She woul turn her back on him, ignored him. She 
would often spend 15 days without speaking to him. Threats and verbal abuse were frequent. After attacking him she made him feel guilty "she knew how to make me feel wrong..." His mother was absent and severe. She had few friends and was very reserved. She would eventually drink alcohol.

The matricide never knew his father. The mother's parental practices were of risk $(-10)$. This evaluation is mostly due to the high rate of negative practices. She neglected him (9), practiced inconsistent punishment, depending on her mood (6), she did stressful monitoring (11) and was physically abusive (2). His accounts on his grandmother's behaviour who raised him until the age of 8 , also revealed severe physical punishment. His mother did not provide moral standards or values, nor monitored his activities.

He started using drugs at the age of 12 with neighbors. He used almost all kinds of drugs, but considered that was crack that "broke" him. He was using drugs at home on the crime day, which he seldom did. His mother arrived from work, saw him using drugs and started to complain about it. He wanted to get away, but his mother did not allow it, closed the door and hid the keys. When he found the keys, she stayed on his way, got a knife in the sink drawer and attacked him. She said she preferred seeing him dead than in such situation. He tried to get the knife and everything went blank. When he recovered consciousness he realized he had blood all over his body and his mother was dead on the floor. Despaired and not knowing what to do, he left with no destination. He thought about turning himself in to the police, calling his family and telling them what happened, but did not know what to say. He came back home, dug a hole in the backyard and buried her. On the next day, he went to the Police Station to report his mother's disappearance. Four days later the body was found by the police and he turned himself in.

\section{Discussion}

The relationships between the parricides and their parents (the victims) were marked by severe physical and psychological abuse, as well as neglect concerning feeding, medical and educational aspects. These are risk factors in the development of offensive and antisocial behavior (Heidi 2013; Gomide, 2010, Palermo, 2010; Patterson, Reid \& Dishion, 1992). Evidence of negative parental practices in the parricides' life 
history corroborates with researches about antisocial behavior, pointing positive correlation between physical abuse, neglect and lack of positive monitoring and moral behavior (Heide, 2013; Rock, 2012; Gomide, 2010; Reid, Patterson \& Snyder, 2002; Nurco \& Lerner, 1996).

All participants were adults without a history of mental illness. All of them were drug abusers. Two of them involved themselves with the law due to theft to buy drugs. Drug abuse is related to the lack of care and poor relationship with the fatherin family context, mainly to the deficit of teaching moral values (Guimarães, Hochgraf, Brasiliano \& Ingbermann, 2009; Haapasoloa e Pokelaa, 1999; Nurco \& Lerner, 1996).

Besides physical abuse, all of them were neglected in different forms. All of them had poor schooling and had to work in order to help their families. Their parents severely neglected their school education. Gallo (2013) showed that schooling is a strong protective factor to delinquent behavior. Lack of attention and love were constantly mentioned by the interviewed parricides. Negligence could be more dangerous to the development of the individual than other forms of abuse (Heidi, 2013; Bolwby, 1988). Neglectful parental relationships have a lack of warmth and love; parents are not responsive, do not know their child's needs and preferences, make eye contact, smile to their child or give attention; they do not assume their responsibilities as a parent and withdraw from difficult situations; they have limited skills in child rearing practices and do not know how to establish limits, rules of behavior or compliment; and they model their child's behavior using repeated physical abuse (Gomide, 2003, 2004, 2006; Heidi, 2013). Their children are emotionally fragile and aggressive in interpersonal relationships (Dodge, Petit e Battes, 1994).

The victims seemed to act as a trigger in the crime. In the first case, the father did not allow his son to get into the house, grabbed him by the neck and prevented his entry, after which the son left followed by his father's teases. Trying to defend himself, the son picked up a stone and hit his father's head. In the second case, the father started arguing with his son about dinner, throwing a glass of juice at the wall, calling him a "cuckold". When his son took an iron bar and hit the father's head, he asked him to kill him, saying "you can end up killing me my son, I deserve to die, I' $m$ paying for what I did". In the third case, the mother threatened her son with a knife, saying she would rather see him dead than drugged. The son then took the knife and stabbed her. It should be noticed that this instrumental role of the victim in the crime was also observed by Newhill (1991). 
Psychological and biological effects probably remained with the parricides over their lifetime until the day of the crime, since there were no reports of psychotherapy or other treatments. They apparently used violence to get rid of years of abuse (Heide, 1992, 2003, 2011; Gomide, 2010; Pinheiro, 2011; Myers \& Vo, 2012). The participants were seriously harmed by their parents, who did not fulfill their parental roles. All of them reported a "sense of relief" after the crime. This fact seems to indicate that killing the father or the mother was the alternative to cease the suffering (Heide, 1992, 2011; Gomide, 2010; West \& Feldsher, 2010; Pinheiro, 2011; Myers \& Vo, 2012).

\section{Conclusion}

Media portrays parricides as monsters, the ones who dared to take the lives of those who gave birth to and raised them. This mistaken and sensationalist view makes their social reintegration very difficult, as they are seldom able return to their hometown or work under this stigma.

Abused women have been receiving proper understanding of law operators, who consider them victims of continuous beatings and therefore authors of murders on selfdefense. Nevertheless, the same does not apply to parricides. On the contrary, most of them are severely judged and treated, during the trial and in prison, and are considered more dangerous than murderers who kill for the purpose of robbing.

Seeking to contribute to a better understanding of the crime and, subsequently, indicating the best way to reintegrate this individual into society, it is suggested that they receive treatment to reduce the biological effects of child abuse, particularly PTSD, as well as a careful forensic assessment in order to identify other psychological and biological areas that might have been affected by the parricide's life story.

Though our research sample was a reduced one, the data gathered corroborate with other authors on parricide (Heidi, 2013, Pinheiro, 2011, Gomide, 2010). Evaluation of parental practices of parricides ' parents is an additional contribution to studies in this field.

\section{Referências}


American Psychiatric Association (2000). Diagnostic and statistical manual of mental disorders (4th ed., text revision). Washington, DC: Author.

Bourget, D., Gagne P., \& Labelle, M. E., (2007). Parricide: A Comparative Study of Matricide Versus Patricide, Journal Am Acad Psychiatry Law 35, 306-312.

Bolwby, J. (1988). A secure base: Parent-child attachment and healthy human development. New York: Basic Books.

Casoy, I. (2006). O Quinto Mandamento: caso de polícia.[ The Fifth Commandment: police case] São Paulo: Ediouro, p. 42-105

Dodge, K. A., Petit, G. S., \& Battes, J. E. (1994). Socialization mediators of the relation between socioeconomic status and child conduct problems. Child Development, 65, 649-65.

Eckstein, N. J. (2004). Emergent issues in families experiencing adolescent-to-parent abuse. Western Journal of Communications, 68 (4), 365-388.

Eisikovits, Z.,Winstok, Z., \& Enosh, G. (1998). Children's experience of interparental violence: A heuristic model. Children and Youth Services Review, 20, 547-568.

Ferreira, M. P. C. (2010). Matar pai e mãe: uma análise antropológica de processos judiciais de parricídio [Kill father and mother: an anthropological analysis of lawsuits parricide]. Universidade Estadual de Campinas, SP / Instituto de Filosofia e Ciências Humanas (PhD Dissesrtation).

Gallo, A.E. (2013). Brazilian Young Offenders: Profile and Risk Factors for Criminal Behavior. International Journal of Criminology and Sociology, p. 163-168, 2013.

Gomide, P.I.C. (2003). Estilos parentais e comportamento antissocial. In Del Prette, Z \& Del Prette, A. Habilidades sociais, desenvolvimento e aprendizagem: questões conceituais, avaliação e intervenção. Campinas: Alínea Editora.

Gomide, P. I. C. (2006). Inventário de estilos parentais: Modelo teórico, manual de aplicação, apuração e interpretação. Petrópolis, RJ: Vozes

Gomide, P. I. C. (2010). Abuso, negligência e parricídio: um estudo de caso. Temas em Psicologia, Vol. 18, Nº 1, 219-230. 
Gomide, P. I. C., Teche, A. M. F., Maiorki, S. \& Cardoso, S. M. N. (2013). Incidência de Parricídio no Brasil. Temas em Psicologia, Vol. 21, № 1, 283-295.

Guimarães, a. B. P. ; Hochgraf, p. B. ; Brasiliano, s. ; Iingberman, Y. K. . (2009). Aspectos familiares de meninas adolescentes dependentes de álcool e drogas. Revista de Psiquiatria Clínica, v. 36, p. 63.

Green C. M. (1981). Matricide by sons. Medicine, Science, and the Law, 21, 207-214.

Haapasoloa, J. \& Pokelaa, E. (1999). Child-rearing and abuse antecedents of criminality. Journal Aggression and Violent Behavior, 4, 107-127.

Heide, K.M. (1992). Why Kids Kill Parents. Columbus, Oh: Ohio State University Press. Heide, K.M. (1993). Weapons used by Juveniles and Adults to Kill Parents. Behavioral Sciences and Law, Vol. 11, 397-405.

Heide, K. M. (1994). Evidence of Child Maltreatment Among Adolescent Parricide Offenders. International Journal of Offender Therapy and Comparative Criminology, $38,151$.

Heide, K. M. (2003). Youth homicide: A review of the literature and a blueprint for action. International Journal of Offender Therapy and Comparative Criminology, 47 (1), 6-36.

Heide, K. M. \& Petee, T. A. (2007). Weapons Used by Juveniles and Adult Offenders in U.S. Parricide Cases. Journal of Interpersonal Violence, Vol. 22, Nº 11, 1400-1414.

Heide, K. M. (2013). Understanding Parricide: When Sons and Daughters Kill Parents. Oxford University Press, Oxford, USA.

Hillbrand, M. Alexandre, J. W., Young, J. L. \& Spitz, R. T. (1999). Parricides: Characters of offenders and victims, legal factors, and treatment issues. Aggression and violent behavior 4: 179-190.

Hillbrand, M. (2010). Commentary: Addressing Suicidality in the Treatment of Parricidal Offenders, J Am Acad Psychiatry Law 38:221-2

Marleau, J.D. (2002). Parricide et caracteristiques de la fatrie dês agresseurs. Canadian Journal of Criminology. 77-96, Jan. 
Marleau, J. D., Millaud, F. \& Auclair, N. (2003). A comparison of parricide and attempted parricide: A study of 39 psychotic adults. International Journal of Law and Psychiatry, $26,269-279$.

Myers, W. C. \& Vo, E. J. (2012). Adolescent Parricide and Psychopathy. Int J Offender Ther Comp Criminol, 56, 715-729.

Newhill, C. E. (1991). Parricide. Journal of Family Violence, 6 (4), 375-394.

Nurco, D. N. \& Lerner, M. (1996). Vulnerability to narcotic addiction: family structure and functioning. Journal of Drug Issues, 26, 1007-1025

Pagani, L., Tremblay, R.; Nagin, D; Zoccolillo, M; Vitaro, F. \& McDuff, P. (2004). Risk Factor models for adolescent verbal and physical aggression toward others. International Journal of Behavioral Development, 28 (6), 528-537.

Palermo, G.B. (2010). Parricide: Crime against nature. International Journal of Offender Therapy and Comparative Criminology, Vol. 54, No 1, 3-5.

Patterson, G; Reid, J. \& Dishion, T. (1992). Antisocial Boys. Castalia Publishing Company, Oregon, USA.

Pinheiro, D. P. N. (2011). Três Casos de Parricídio? Passagem ao ato em diferentes configurações psicopatológicas. Psicologia Clínica. Pontifícia Universidade Católica de São Paulo, SP. (tese de doutorado).

Reid, J.B.; Patterson, G.R. \& Snyder, J. (2002). Antisocial Behavior in Children and Adolescents: A Developmental Analysis and Model for Intervention. American Psychological Association, Washington, DC.

Roe-Sepowitz, D. E. (2009). Comparing Male and Female Juveniles Charged With Homicide: Child Maltreatment, Substance Abuse, and Crime Details. Journal of Interpersonal Violence, Vol. 24, $\mathrm{N}^{\mathrm{o}} 4$.

Rocha, G. M. (2012). Psicoterapia analítico-comportamental em adolescentes infratores de alto risco. Editora Juruá. Curitiba.

Shon, P. C. H. \& Roberts, M. A. (2010). An Archival Exploration of Homicide-Suicide and Mass Murder in the Context of 19th-Century American Parricides. International Journal of Offender Therapy and Comparative Criminology. Vol. $54 \mathrm{~N}^{\circ} 1,43-60$

PsicolArgum. 2018 jul./set., 36(93), 296-312 
Walsh, J. A., Krienert, J. L., \& Crowder, D. (2008). Innocence lost: A gender based study of parricide offenders, victims, and incident based characteristics in a national sample, 1976-2003. Journal of Aggression, Maltreatment, and Trauma, 16(2), 202-227.

Walsh, J. A. \& Krienert, J. L. (2009). A Decade of Child-Initiated Family Violence Comparative Analysis of Child-Parent Violence and Parricide Examining Offender, Victim, and Event Characteristics in a National Sample of Reported Incidents, 19952005. Journal of Interpersonal Violence, Vol. $24 \mathrm{~N}^{\mathrm{o}}$ 9, 1450-1477

Weisman, A. M., \& Sharma K. K. (1997). Forensic Analysis and Psycholegal Implications of Parricide and Attempted Parricide. Journal Forensic Sci, Vol. $42 \mathrm{~N}^{\mathrm{o}}$ 6, 1107-1113.

West, S. G. \& Feldsher, M. (2010). Parricide: Characteristics of sons and daughters who kill their parents. Current Psychiatry, Vol. 9, No 11, 20-38.

Wertham, F. (1941). Dark legend: A study in murder. New York: Duell, Sloan, \& Pearce. 